\title{
Comparison of Hydrogen Specification in National Standards for China
}

\author{
Yanmei Yang*, Geng Wang, Lan Zhang, Sinan Zhang and Ling Lin \\ China National Institute of Standardization, Beijing, China
}

\begin{abstract}
Hydrogen specifications for different scenarios are various. Based on national standards for China, a comparison of hydrogen specification standards is discussed in this paper, including specification standards for industrial hydrogen, pure hydrogen, high pure hydrogen, ultrapure hydrogen, hydrogen for electronic industry and hydrogen for PEM FCVs. Hydrogen purity for electronic industry is greater than that for industrial hydrogen, pure hydrogen and hydrogen for PEM FCVs. Specifications of general contaminants in hydrogen for electronic industry, including $\mathrm{H}_{2} \mathrm{O}, \mathrm{O}_{2}, \mathrm{~N}_{2}, \mathrm{CO}, \mathrm{CO}_{2}$ and total hydrocarbons, are stricter than that in hydrogen for PEM FCVs. Hydrogen purity for PEM FCVs is less than that for electronic industry and pure hydrogen. However, contaminants in hydrogen for PEM FCVs are strict. Contaminants in hydrogen for PEM FCVs should include not only $\mathrm{H}_{2} \mathrm{O}, \mathrm{O}_{2}, \mathrm{~N}_{2}, \mathrm{CO}, \mathrm{CO}_{2}$, Ar and total hydrocarbons, but also helium, total sulfur compounds, formaldehyde, formic acid, ammonia, halogenated compounds and particulates.
\end{abstract}

\section{Introduction}

Hydrogen has garnered more and more interest in recent years for its near-zero emission and abundant source. As is summarized by hydrogen council, hydrogen can play major roles in enabling large-scale renewable energy integration and power generation, distributing energy across sectors and regions, acting as a buffer to increase energy system resilience, decarbonizing transportation, decarbonizing industrial energy use, decarbonizing building heat and power, and providing clean feedstock for industry. Across the seven roles, hydrogen could account for $18 \%-20 \%$ of total energy consumption by 2050 , reducing annual $\mathrm{CO}_{2}$ emission by roughly $60 \mathrm{Gt}$ compared to today's technologies ${ }^{[1]}$.

Hydrogen economy is developing rapidly in China. By the end of 2018, more than 25 cities have announced to support the deployment of hydrogen industry. The cumulative sales number of hydrogen fuel cell vehicles reached 3428. About 23 hydrogen fuelling stations are in operation. More than 40 hydrogen fuelling stations are in construction and planning ${ }^{[2,3]}$.

Hydrogen is a secondary energy, which can be produced by coal gasification, steam reforming of natural gas, industrial gas purification, water electrolysis ${ }^{[4]}$, etc. Hydrogen specifications for different scenarios are various. According to national standards for China, a comparison of hydrogen specification standards is discussed in this paper, including standards for industrial hydrogen, pure hydrogen, high pure hydrogen, ultrapure hydrogen, hydrogen for electronic industry and hydrogen for proton exchange membrane fuel cell vehicles (PEM FCVs). Organization of this paper is as follows:
In session 2, national standards for hydrogen specification are listed.

In session 3, a comparison of hydrogen specification in national standards is discussed, including hydrogen purity, total non-hydrogen gases and contaminants. In session 4 , main conclusions are summarized.

\section{National standards for hydrogen specification}

As is shown in Table 1, there are five national standards for hydrogen specification in China. GB/T 3634.1-2006 specify the specification and requirements of testing, packing, storage, transportation and safety of industrial hydrogen. It is developed for petroleum, food, fine chemicals, glass and artificial gems manufacturing, metal smelting, cutting and welding industries. GB/T 3634.2-2011 specify the specification and requirements of testing, packing, storage, transportation and safety of pure hydrogen, high pure hydrogen and ultrapure hydrogen. It is developed for electronic, petrochemical, metal smelting industries, and scientific research. GB/T 16942-2009 specify the the specification and requirements of testing, packing, storage, transportation and safety of gaseous hydrogen for electronic industries. It is used as reducing gas, carrier gas for epitaxy process and gas for plasma etch. GB/T 34537-2017 specify the specification and requirements of hydrogen and compressed natural gas (HCNG) blends for vehicles. In this standard, it is specified that hydrogen used for HCNG blending should comply with GB/T 3634.1. GB/T 34537-2017 will not be discussed in this paper. GB/T 37244-2018 is now the only hydrogen fuel specification for proton exchange membrane fuel cell

\footnotetext{
*Corresponding author: yangym11thu@163.com
} 
vehicles. Hydrogen fuel purity, contaminants and testing methods for contaminants are specified in this standard.

Table 1. National standards for hydrogen specification

\begin{tabular}{|c|l|l|}
\hline No. & Standard Number & \multicolumn{1}{|c|}{ Name of Standard } \\
\hline 1 & GB/T 3634.1-2006 & $\begin{array}{l}\text { Hydrogen-Part 1: } \\
\text { Industrial hydrogen }\end{array}$ \\
\hline 2 & GB/T 3634.2-2011 & $\begin{array}{l}\text { Hydrogen - Part 2: Pure } \\
\text { hydrogen, high pure } \\
\text { hydrogen and ultra-pure } \\
\text { hydrogen }\end{array}$ \\
\hline 3 & GB/T 16942-2009 & $\begin{array}{l}\text { Hydrogen for electronic } \\
\text { industry }\end{array}$ \\
\hline 4 & GB/T 34537-2017 & $\begin{array}{l}\text { Hydrogen and compressed } \\
\text { natural gas (HCNG) blended } \\
\text { as vehicle fuel }\end{array}$ \\
\hline 5 & GB/T 37244-2018 & $\begin{array}{l}\text { Fuel specification for proton } \\
\text { exchange membrane fuel } \\
\text { cell vehicles-Hydrogen }\end{array}$ \\
\hline
\end{tabular}

\section{Comparison of national standards for hydrogen specification}

\subsection{Hydrogen purity}

Table 2 shows the specification of hydrogen purity for different scenarios. As is specified in GB/T 3634.1, industrial hydrogen is classified into three grades, excellent grade (hydrogen purity $\geqslant 99.95 \%$ ), first grade (hydrogen purity $\geqslant 99.50 \%$ ) and qualified grade (hydrogen purity $\geqslant 99.00 \%$ ). According to $\mathrm{GB} / \mathrm{T}$ 3634.2-2011, hydrogen is classified into three grades, including pure hydrogen (hydrogen purity $\geqslant 99.99 \%$ ), high pure hydrogen (hydrogen purity $\geqslant 99.999 \%$ ) and ultrapure hydrogen (hydrogen purity $\geqslant 99.9999 \%$ ). As is specified in GB/T 16942-2009, hydrogen for electronic industry is marked as three grades, involving Grade I (hydrogen purity $\geqslant 99.9999 \%$ ), Grade II (hydrogen purity $\geqslant 99.9997 \%$ ) and Grade III (hydrogen purity $\geqslant 99.9995 \%$ ). Hydrogen fuel for PEM FCVs is specified in GB/T 37244-2018. Hydrogen purity should not be less than $99.97 \%$, which is greater than that of industrial hydrogen but less than that of pure hydrogen and hydrogen for electronic industry. Hydrogen for electronic industry specify the strictest hydrogen purity.

Table 2. Specification of hydrogen purity in national standards

\begin{tabular}{|c|c|c|c|}
\hline \multicolumn{2}{|c|}{ Standard No. } & Grade & $\begin{array}{c}\text { Hydrogen } \\
\text { purity } \\
(\%)\end{array}$ \\
\hline \multirow{3}{*}{$\begin{array}{l}\mathrm{GB} / \mathrm{T} \\
2006\end{array}$} & \multirow{3}{*}{ 3634.1- } & Excellent grade & $\geqslant 99.95$ \\
\hline & & First grade & $\geqslant 99.50$ \\
\hline & & Qualified grade & $\geqslant 99.00$ \\
\hline \multirow{3}{*}{$\begin{array}{l}\mathrm{GB} / \mathrm{T} \\
2011\end{array}$} & \multirow{3}{*}{ 3634.2- } & Pure hydrogen & $\geqslant 99.99$ \\
\hline & & $\begin{array}{l}\text { High pure } \\
\text { hydrogen }\end{array}$ & $\geqslant 99.999$ \\
\hline & & $\begin{array}{l}\text { Ultrapure } \\
\text { hydrogen }\end{array}$ & $\geqslant 99.9999$ \\
\hline
\end{tabular}

\begin{tabular}{|c|c|c|c|}
\hline \multirow{3}{*}{$\begin{array}{l}\mathrm{GB} / \mathrm{T} \\
2009^{*}\end{array}$} & \multirow{3}{*}{ 16942- } & Grade I & $\geqslant 99.9999$ \\
\hline & & Grade II & $\geqslant 99.9997$ \\
\hline & & Grade III & $\geqslant 99.9995$ \\
\hline $\begin{array}{l}\mathrm{GB} / \mathrm{T} \\
2018 \\
\end{array}$ & 37244- & $\begin{array}{l}\text { Hydrogen fuel for } \\
\text { PEM FCVs }\end{array}$ & $\geqslant 99.97$ \\
\hline
\end{tabular}

\subsection{Contaminants in hydrogen}

\subsubsection{Total non-hydrogen gases}

Total non-hydrogen gases include water, hydrocarbons, oxygen $\left(\mathrm{O}_{2}\right)$, helium $(\mathrm{He})$, nitrogen $\left(\mathrm{N}_{2}\right)$, argon $(\mathrm{Ar})$, carbon dioxide $\left(\mathrm{CO}_{2}\right)$, carbon monoxide $(\mathrm{CO})$, total sulfur compounds, formaldehyde (HCHO), formic acid $(\mathrm{HCOOH})$, ammonia $\left(\mathrm{NH}_{3}\right)$, total halogenated compounds, particulates, etc. Table 3 lists the specification of total non-hydrogen gases in hydrogen. For industrial hydrogen and pure hydrogen there is no specific limitation of non-hydrogen gases. For high pure hydrogen, ultrapure hydrogen and hydrogen fuel for PEM FCVs, content of total non-hydrogen gases should not exceed content of total gases except hydrogen. Content of non-hydrogen gases in hydrogen for electronic industry is less than others. As is specified in GB/T 16942-2009, content of non-hydrogen gases should be less than or equal to $1.0 \mu \mathrm{mol} / \mathrm{mol}, 2.8$ $\mu \mathrm{mol} / \mathrm{mol}$ and $4.5 \mu \mathrm{mol} / \mathrm{mol}$ separately for Grade I, Grade II and Grade III hydrogen.

Table 3. Specification of total non-hydrogen gases in hydrogen

\begin{tabular}{|c|c|c|c|}
\hline \multicolumn{2}{|c|}{ Standard No. } & Grade & $\begin{array}{c}\text { Total non- } \\
\text { hydrogen } \\
\text { gases } \\
(\mu \mathrm{mol} / \mathrm{mol})\end{array}$ \\
\hline \multirow{3}{*}{$\begin{array}{l}\mathrm{GB} / \mathrm{T} \\
2006\end{array}$} & \multirow{3}{*}{$3634.1-$} & Excellent grade & / \\
\hline & & First grade & 1 \\
\hline & & Qualified grade & 1 \\
\hline \multirow{3}{*}{$\begin{array}{l}\mathrm{GB} / \mathrm{T} \\
2011\end{array}$} & \multirow{3}{*}{$3634.2-$} & Pure hydrogen & 1 \\
\hline & & High pure hydrogen & $\leqslant 10$ \\
\hline & & Ultrapure hydrogen & $\leqslant 1$ \\
\hline \multirow{3}{*}{$\begin{array}{l}\mathrm{GB} / \mathrm{T} \\
2009\end{array}$} & \multirow{3}{*}{ 16942- } & Grade I & $\leqslant 1.0$ \\
\hline & & Grade II & $\leqslant 2.8$ \\
\hline & & Grade III & $\leqslant 4.5$ \\
\hline $\begin{array}{l}\mathrm{GB} / \mathrm{T} \\
2018\end{array}$ & 37244- & $\begin{array}{l}\text { Hydrogen fuel for } \\
\text { PEM FCVs }\end{array}$ & $\leqslant 300$ \\
\hline
\end{tabular}

\subsection{Contaminants}

Table 4-1 and Table 4-2 show the specification of contaminants in hydrogen. Industrial hydrogen specify four kinds of contaminants, including $\mathrm{H}_{2} \mathrm{O}, \mathrm{O}_{2}, \mathrm{~N}_{2}$, and Ar. Pure, high pure and ultrapure hydrogen specify seven kinds of contaminants, including $\mathrm{H}_{2} \mathrm{O}, \mathrm{O}_{2}, \mathrm{~N}_{2}$, Ar, $\mathrm{CO}$, $\mathrm{CO}_{2}$, and $\mathrm{CH}_{4}$. Hydrogen for electronic industry also specify seven kinds of contaminants, including $\mathrm{H}_{2} \mathrm{O}, \mathrm{O}_{2}$, $\mathrm{N}_{2}, \mathrm{CO}, \mathrm{CO}_{2}$, hydrocarbons, and particulates. Though the hydrogen purity of hydrogen for PEM FCVs is less than that of pure hydrogen and hydrogen for electronic 
industry, specifications of contaminants in hydrogen for PEM FCVs are strict, including $\mathrm{H}_{2} \mathrm{O}, \mathrm{O}_{2}, \mathrm{~N}_{2}, \mathrm{He}, \mathrm{Ar}, \mathrm{CO}$, $\mathrm{CO}_{2}$, hydrocarbons, total sulfur compounds, formaldehyde (HCHO), formic acid $(\mathrm{HCOOH})$, ammonia $\left(\mathrm{NH}_{3}\right)$, total halogenated compounds, and particulates.

Table 4-1. Specification of contaminants in hydrogen

\begin{tabular}{|c|c|c|c|c|c|c|c|c|c|}
\hline \multirow[t]{2}{*}{$\begin{array}{c}\text { Standard } \\
\text { No. }\end{array}$} & \multirow[t]{2}{*}{ Grade } & $\begin{array}{l}\text { Water } \\
\left(\mathrm{H}_{2} \mathrm{O}\right)\end{array}$ & $\begin{array}{c}\text { Oxygen } \\
\left(\mathrm{O}_{2}\right)\end{array}$ & $\begin{array}{c}\text { Nitrogen } \\
\left(\mathrm{N}_{2}\right)\end{array}$ & $\begin{array}{c}\text { Argon } \\
\text { (Ar) }\end{array}$ & $\begin{array}{c}\text { Helium } \\
\text { (He) }\end{array}$ & $\begin{array}{l}\text { Carbon } \\
\text { monoxide } \\
\text { (CO) }\end{array}$ & $\begin{array}{c}\text { Carbon } \\
\text { dioxide } \\
\left(\mathrm{CO}_{2}\right)\end{array}$ & $\begin{array}{c}\text { Total } \\
\text { hydro- } \\
\text { carbons } \\
\left(\mathrm{CH}_{4}\right. \\
\text { basis }) \\
\end{array}$ \\
\hline & & $(\mu \mathrm{mol} / \mathrm{mol})$ & $(\mu \mathrm{mol} / \mathrm{mol})$ & $(\mu \mathrm{mol} / \mathrm{mol})$ & $(\mu \mathrm{mol} / \mathrm{mol})$ & $(\mu \mathrm{mol} / \mathrm{mol})$ & $(\mu \mathrm{mol} / \mathrm{mol})$ & $(\mu \mathrm{mol} / \mathrm{mol})$ & $(\mu \mathrm{mol} / \mathrm{mol})$ \\
\hline \multirow[b]{3}{*}{$\begin{array}{l}\mathrm{GB} / \mathrm{T} \\
3634.1- \\
2006\end{array}$} & $\begin{array}{l}\text { Excellent } \\
\text { grade }\end{array}$ & $\begin{array}{l}\text { dew point } \\
\leq-43{ }^{\circ} \mathrm{C}\end{array}$ & $\leq 0.01 \%$ & \multicolumn{2}{|l|}{$\leq 0.04 \%$} & I & I & I & / \\
\hline & $\begin{array}{l}\text { First } \\
\text { grade }\end{array}$ & $\begin{array}{l}\text { no free } \\
\text { water }\end{array}$ & $\leq 0.02 \%$ & \multicolumn{2}{|l|}{$\leq 0.30 \%$} & l & l & & \\
\hline & $\begin{array}{l}\text { Qualified } \\
\text { grade }\end{array}$ & $\begin{array}{l}\text { free water } \\
\text { content } \leq \\
100 \\
\mathrm{~mL} / 40 \mathrm{~L} \\
\text { gas } \\
\text { cylinder }\end{array}$ & $\leq 0.40 \%$ & \multicolumn{2}{|l|}{$\leq 0.60 \%$} & / & I & / & / \\
\hline \multirow{3}{*}{$\begin{array}{l}\mathrm{GB} / \mathrm{T} \\
3634.2- \\
2011\end{array}$} & $\begin{array}{l}\text { Pure } \\
\text { hydrogen }\end{array}$ & $\leq 10$ & $\leq 5$ & $\leq 60$ & TBD & I & $\leq 5$ & $\leq 5$ & $\mathrm{CH}_{4} \leq 10$ \\
\hline & $\begin{array}{l}\text { High } \\
\text { pure } \\
\text { hydrogen }\end{array}$ & $\leq 3$ & $\leq 1$ & $\leq 5$ & TBD & I & $\leq 1$ & $\leq 1$ & $\mathrm{CH}_{4} \leq 1$ \\
\hline & $\begin{array}{l}\text { Ultrapure } \\
\text { hydrogen }\end{array}$ & $\leq 0.5$ & $\begin{array}{l}\mathrm{O}_{2}+\mathrm{Ar} \leq \\
0.2\end{array}$ & $\leq 0.4$ & $\begin{array}{l}\mathrm{O}_{2}+\mathrm{Ar} \leq \\
0.2\end{array}$ & l & $\leq 0.1$ & $\leq 0.1$ & $\mathrm{CH}_{4} \leq 0.2$ \\
\hline \multirow{3}{*}{$\begin{array}{l}\text { GB/T } \\
16942- \\
2009\end{array}$} & Grade I & $<0.2$ & $<0.2$ & $<0.5$ & 1 & 1 & $<0.05$ & $<0.05$ & $<0.05$ \\
\hline & Grade II & $<0.2$ & $<0.2$ & $<2.0$ & 1 & 1 & \multicolumn{2}{|l|}{$<0.2$} & $<0.2$ \\
\hline & Grade III & $<0.5$ & $<0.5$ & $<2$ & 1 & 1 & $<0.5$ & $<0.5$ & $<0.5$ \\
\hline $\begin{array}{l}\mathrm{GB} / \mathrm{T} \\
37244- \\
2018\end{array}$ & $\begin{array}{l}\text { Hydrogen } \\
\text { fuel for } \\
\text { PEM } \\
\text { FCVs }\end{array}$ & $\leq 5$ & $\leq 5$ & $\leq 100$ & & $\leq 300$ & $\leq 0.2$ & $\leq 2$ & $\leq 2$ \\
\hline
\end{tabular}

* TBD means to be determined by suppliers and demanders

Table 4-2. Specification of contaminants in hydrogen

\begin{tabular}{|c|c|c|c|c|c|c|c|}
\hline \multirow[t]{2}{*}{$\begin{array}{c}\text { Standard } \\
\text { No. }\end{array}$} & \multirow[t]{2}{*}{ Grade } & $\begin{array}{l}\text { Total sulfur } \\
\text { compounds } \\
\text { ( } \mathrm{H}_{2} \mathrm{~S} \text { basis) }\end{array}$ & $\begin{array}{l}\text { Formaldehyde } \\
\text { (HCHO) }\end{array}$ & $\begin{array}{c}\text { Formic acid } \\
\text { (HCOOH) }\end{array}$ & $\begin{array}{c}\text { Ammonia } \\
\left(\mathrm{NH}_{3}\right)\end{array}$ & $\begin{array}{c}\text { Total } \\
\text { halogenated } \\
\text { compounds } \\
\text { (Halogenate } \\
\text { ion basis) }\end{array}$ & $\begin{array}{c}\text { Maximum } \\
\text { particulates } \\
\text { concentration }\end{array}$ \\
\hline & & $(\mu \mathrm{mol} / \mathrm{mol})$ & $(\mu \mathrm{mol} / \mathrm{mol})$ & $(\mu \mathrm{mol} / \mathrm{mol})$ & $(\mu \mathrm{mol} / \mathrm{mol})$ & $(\mu \mathrm{mol} / \mathrm{mol})$ & $(\mathrm{mg} / \mathrm{kg})$ \\
\hline \multirow{3}{*}{$\begin{array}{l}\mathrm{GB} / \mathrm{T} \\
16942- \\
2009\end{array}$} & Grade I & l & I & I & l & I & TBD \\
\hline & Grade II & 1 & 1 & 1 & 1 & 1 & TBD \\
\hline & Grade III & 1 & 1 & 1 & 1 & 1 & TBD \\
\hline $\begin{array}{l}\mathrm{GB} / \mathrm{T} \\
37244- \\
2018\end{array}$ & $\begin{array}{l}\text { Hydrogen } \\
\text { fuel for } \\
\text { PEM } \\
\text { FCVs }\end{array}$ & $\leqslant 0.004$ & $\leqslant 0.01$ & $\leqslant 0.2$ & $\leqslant 0.1$ & $\leqslant 0.05$ & $\leqslant 1$ \\
\hline
\end{tabular}

\footnotetext{
* TBD means to be determined by suppliers and demanders
}

\section{(1) Water}

As is specified in GB/T 3634.1-2006, dew point of excellent hydrogen should not be greater than $-43{ }^{\circ} \mathrm{C}$. There should be no free water in first grade hydrogen. Free water content in qualified hydrogen should not be greater than $100 \mathrm{~mL} / 40 \mathrm{~L}$ gas cylinder. If qualified hydrogen is transported by piping or other packing forms, water content can be determined by suppliers and demanders.

As is specified in GB/T 3634.2-2011, water content in pure, high pure and ultrapure hydrogen should 
separately be less than or equal to $10 \mu \mathrm{mol} / \mathrm{mol}, 3$ $\mu \mathrm{mol} / \mathrm{mol}$ and $0.5 \mu \mathrm{mol} / \mathrm{mol}$.

As is specified in GB/T 16942-2009, water content in hydrogen for electronic industry should be less than 0.2 $\mu \mathrm{mol} / \mathrm{mol}, 0.2 \mu \mathrm{mol} / \mathrm{mol}$ and $0.5 \mu \mathrm{mol} / \mathrm{mol}$ separately for Grade I, Grade II and Grade III hydrogen. The limitation of water content in hydrogen for electronic industry is less than that in the other hydrogen.

Water content in hydrogen for PEM FCVs should be less than or equal to $5 \mu \mathrm{mol} / \mathrm{mol}$ according to $\mathrm{GB} / \mathrm{T}$ 37244-2018.

\section{(2) Oxygen $\left(\mathrm{O}_{2}\right)$}

According to GB/T 3634.1-2006, oxygen content in industrial hydrogen is specified to be less than or equal to $0.01 \%, 0.20 \%$ and $0.40 \%$ separately for excellent grade, first grade and qualified grade hydrogen.

Oxygen content in pure and high pure hydrogen is separately specified to be less than or equal to 5 $\mu \mathrm{mol} / \mathrm{mol}$ and $1 \mu \mathrm{mol} / \mathrm{mol}$. For ultrapure hydrogen, total contents of oxygen and argon should be less than or equal to $0.2 \mu \mathrm{mol} / \mathrm{mol}$.

As is specified in GB/T 16942-2009, oxygen content should be less than $0.2 \mu \mathrm{mol} / \mathrm{mol}$ for Grade I and Grade II hydrogen. While oxygen content should be less than $0.5 \mu \mathrm{mol} / \mathrm{mol}$ for Grade III hydrogen.

Oxygen content in hydrogen for PEM FCVs should be less than or equal to $5 \mu \mathrm{mol} / \mathrm{mol}$, the same as that of pure hydrogen.

\section{(3) Nitrogen ( $\left.\mathbf{N}_{2}\right)$, Argon (Ar) and Helium (He)}

Nitrogen, argon and helium are inert constituents. However, they dilute the hydrogen gas. For industrial hydrogen, total content of nitrogen and argon should separately be less than or equal to $0.04 \%, 0.30 \%$ and $0.60 \%$ for excellent grade, first grade and qualified grade hydrogen.

Nitrogen content in pure hydrogen, high pure hydrogen and ultrapure hydrogen should separately be less than or equal to $60 \mu \mathrm{mol} / \mathrm{mol}, 5 \mu \mathrm{mol} / \mathrm{mol}$ and 0.4 $\mu \mathrm{mol} / \mathrm{mol}$. Argon content in pure and high pure hydrogen can be determined by suppliers and demanders. Total contents of argon and oxygen should be less than or equal to $0.2 \mu \mathrm{mol} / \mathrm{mol}$ for ultrapure hydrogen.

Nitrogen content of hydrogen for electronic industry should be less than $0.5 \mu \mathrm{mol} / \mathrm{mol}, 2.0 \mu \mathrm{mol} / \mathrm{mol}$ and 2 $\mu \mathrm{mol} / \mathrm{mol}$ separately for Grade I, Grade II and Grade III hydrogen.

Total contents of nitrogen and argon in hydrogen for PEM FCVs should be less than or equal to $100 \mu \mathrm{mol} / \mathrm{mol}$. There is no specification of helium for industrial, pure, high pure, ultrapure and electronic industry used hydrogen. Helium content in hydrogen for PEM FCVs should be less than or equal to $300 \mu \mathrm{mol} / \mathrm{mol}$.

\section{(4) Carbon monoxide (CO)}

As is specified in GB/T 3634.2-2011, CO content in pure, high pure and ultrapure hydrogen should separately be less than or equal to $5 \mu \mathrm{mol} / \mathrm{mol}, 1 \mu \mathrm{mol} / \mathrm{mol}$ and 0.1 $\mu \mathrm{mol} / \mathrm{mol}$.

According to GB/T 16942-2009, CO content in hydrogen for electronic industry should be less than 0.05 $\mu \mathrm{mol} / \mathrm{mol}$ and $0.5 \mu \mathrm{mol} / \mathrm{mol}$ for Grade I and Grade III hydrogen. Total content of $\mathrm{CO}$ and $\mathrm{CO}_{2}$ should be less than $0.2 \mu \mathrm{mol} / \mathrm{mol}$ for Grade II hydrogen.

As is specified in GB/T 37244-2018, content of CO in hydrogen for PEM FCVs should be less than or equal to $0.2 \mu \mathrm{mol} / \mathrm{mol}$.

\section{(5) Carbon dioxide $\left(\mathrm{CO}_{2}\right)$}

As is specified in GB/T 3634.2-2011, $\mathrm{CO}_{2}$ content in pure, high pure and ultrapure hydrogen should separately be less than or equal to $5 \mu \mathrm{mol} / \mathrm{mol}, 1 \mu \mathrm{mol} / \mathrm{mol}$ and 0.1 $\mu \mathrm{mol} / \mathrm{mol}$.

According to $\mathrm{GB} / \mathrm{T}$ 16942-2009, $\mathrm{CO}_{2}$ content in hydrogen for electronic industry should be less than 0.05 $\mu \mathrm{mol} / \mathrm{mol}$ and $0.5 \mu \mathrm{mol} / \mathrm{mol}$ for Grade I and Grade III hydrogen. Total content of $\mathrm{CO}_{2}$ and $\mathrm{CO}$ should be less than $0.2 \mu \mathrm{mol} / \mathrm{mol}$ for Grade II hydrogen.

As is specified in GB/T 37244-2018, content of $\mathrm{CO}_{2}$ in hydrogen for PEM FCVs should be less than or equal to $2 \mu \mathrm{mol} / \mathrm{mol}$.

\section{(6) Total hydrocarbons or methane $\left(\mathrm{CH}_{4}\right)$}

As is specified in GB/T 3634.2-2011, $\mathrm{CH}_{4}$ content in pure, high pure and ultrapure hydrogen should separately be less than or equal to $10 \mu \mathrm{mol} / \mathrm{mol}, 1 \mu \mathrm{mol} / \mathrm{mol}$ and $0.2 \mu \mathrm{mol} / \mathrm{mol}$.

According to $\mathrm{GB} / \mathrm{T} 16942-2009$, total hydrogen carbons $\left(\mathrm{CH}_{4}\right.$ basis $)$ should be less than or equal to 0.05 $\mu \mathrm{mol} / \mathrm{mol}, 0.2 \mu \mathrm{mol} / \mathrm{mol}$ and $0.5 \mu \mathrm{mol} / \mathrm{mol}$ separately for Grade I, Grade II and Grade III hydrogen.

As is specified in GB/T 37244-2018, content of total hydrocarbons $\left(\mathrm{CH}_{4}\right.$ basis) in hydrogen for PEM FCVs should be less than or equal to $2 \mu \mathrm{mol} / \mathrm{mol}$. When total hydrocarbons is greater than $2 \mu \mathrm{mol} / \mathrm{mol}$ due only to the presence of methane, total content of methane, nitrogen and argon should not exceed $100 \mu \mathrm{mol} / \mathrm{mol}$. Oxygenated organic species are included in total hydrocarbons.

\section{(7) Total sulfur compounds}

Total sulfur compounds in hydrogen are only specified in GB/T 37244-2018 for PEM FVCs, which are severe poisons that at even low content can cause irreversible degradation of fuel cell performance ${ }^{[5,6]}$. The specification of total sulfur compound $\left(\mathrm{H}_{2} \mathrm{~S}\right.$ basis $)$ should not exceed $0.004 \mu \mathrm{mol} / \mathrm{mol}$.

Based on the hydrogen production process, sulfur compounds can come from hydrogen production by stream reforming of natural gas, coal gasification, industrial gas purification, etc. $\mathrm{H}_{2} \mathrm{~S}, \mathrm{COS}, \mathrm{CS}_{2}$ and mercaptans should be involved.

\section{(8) Formaldehyde (HCHO) and Formic acid (HCOOH)}

$\mathrm{HCHO}$ and $\mathrm{HCOOH}$ in hydrogen are only specified in GB/T 37244-2018 for PEM FVCs, which similar to CO are severe poisons that adversely affects fuel cell performance ${ }^{[5]}$. Content of HCHO should be less than or equal to $0.01 \mu \mathrm{mol} / \mathrm{mol}$. Content of $\mathrm{HCOOH}$ should be less than or equal to $0.2 \mu \mathrm{mol} / \mathrm{mol}$.

\section{(9) Ammonia $\left(\mathrm{NH}_{3}\right)$}

$\mathrm{NH}_{3}$ in hydrogen is only specified in GB/T 37244-2018 for PEM FVCs, which can cause some irreversible fuel cell performance degradation by affecting the ion exchange capacity of the ionomer of the proton exchange 
membrane and/or electrode ${ }^{[5]}$. Content of $\mathrm{NH}_{3}$ should be less than or equal to $0.1 \mu \mathrm{mol} / \mathrm{mol}$.

\section{(10) Total halogenated compounds}

Total halogenated compounds in hydrogen are only specified in GB/T 37244-2018 for PEM FVCs, which can cause irreversible degradation of fuel cell performance ${ }^{[5]}$. Content of total halogenated compounds (halogenate ion basis) should be less than or equal to $0.05 \mu \mathrm{mol} / \mathrm{mol}$. Halogenated compounds can include hydrogen bromide $(\mathrm{HBr})$, hydrogen chloride $(\mathrm{HCl})$, chlorine $\left(\mathrm{Cl}_{2}\right)$, and organic halides (R-X).

Based on the hydrogen production process, halogenated compounds can come from hydrogen production by chlor-alkali production process, etc.

\section{(11) Particulates}

Particulates content are specified in GB/T 16942-2009 and GB/T 37244-2018. In GB/T 16942-2009, content of particulates in hydrogen for electronic industry can be determined by suppliers and demanders. Maximum particulates concentration should not exceed $1 \mathrm{mg} / \mathrm{kg}$ for PEM FCVs according to GB/T 37244-2018. A maximum particulate size diameter is not specified, but it should be kept as small as possible ${ }^{[5]}$.

\section{Conclusions}

A comparison of national standards for hydrogen specification is discussed in this paper. Based on analysis and comparison, concluding remarks are as follows:

(1) Hydrogen purity for electronic industry is greater than that for industrial hydrogen, pure hydrogen and hydrogen for PEM FCVs.

(2) Specifications of general contaminants in electronic hydrogen, including $\mathrm{H}_{2} \mathrm{O}, \mathrm{O}_{2}, \mathrm{~N}_{2}, \mathrm{CO}, \mathrm{CO}_{2}$ and total hydrocarbons, are stricter than that in hydrogen for PEM FCVs.

(3) Hydrogen purity for PEM FCVs is less than that for electronic industry and pure hydrogen. However, contaminants in hydrogen for PEM FCVs are strict.

(4) Contaminants in hydrogen for PEM FCVs should include not only $\mathrm{H}_{2} \mathrm{O}, \mathrm{O}_{2}, \mathrm{~N}_{2}, \mathrm{CO}, \mathrm{CO}_{2}$, Ar and total hydrocarbons, but also helium, total sulfur compounds, formaldehyde, formic acid, ammonia, halogenated compounds and particulates.

\section{References}

1. Hydrogen Council. Hydrogen scaling up - a sustainable pathway for the global energy transition (2017)

2. China National Instititue of Standardizaiton. Blue book for infrastructure development of hydrogen industry in China (China Quality and Standard Press, 2018)

3. China Hydrogen Alliance. White Book on Hydrogen Energy and Fuel Cell Industry in China (2019)

4. I. Dincer, C. Acar, IJHE 40, 18 (2015)
5. ISO 14682-2:2012 Hydrogen fuel -- Product specification -- Part 2: Proton exchange membrane (PEM) fuel cell applications for road vehicles (2012)

6. V. A. Sethuraman, J. W. Weidner, Electrochimica Acta 55, 12 (2010) 